\title{
Studies on the Site of Renal Salt Loss in a Patient with Bartter's Syndrome
}

\author{
G. Chaimovitz ${ }^{[23]}$, J. Levi, O. S. Better, L. Oslander, and A. Benderli \\ Department of Nephrology, Reba Susan Isenberg Hemodialysis Unit, and Department of Pediatrics A, \\ Rambam Government Hospital, Haifa, Israel
}

\begin{abstract}
Extract
A child with growth retardation, hypokalemic alkalosis, and urinary salt losing is described. Pressor response to angiotensin II was reduced and renal biopsy showed striking hyperplasia of the juxtaglomerular apparatus.

Renal tubular function was studied in the patient and in healthy control subjects during hypotonic saline diuresis. Glomerular filtration rate (GFR) was $128 \mathrm{ml} / \mathrm{min} /$ $1.73 \mathrm{~m}^{2}$ in the patient and $129 \pm 30 \mathrm{ml} / \mathrm{min} / 1.73 \mathrm{~m}^{2}$ in the control subjects. Fractional sodium delivery to the distal nephron, as estimated by $\left(\mathrm{C}_{\mathrm{H}_{2} \mathrm{O}}+\mathrm{C}_{\mathrm{Na}}\right) / 100 \mathrm{ml}$ GFR, was $13.3 \mathrm{ml}$ and $11.1 \pm 3.5 \mathrm{ml}$ in the patient and normal subjects, respectively. Sodium transport at the diluting segment $\left[\left(\mathrm{C}_{\mathrm{H}_{2} \mathrm{O}} / \mathrm{G}_{\mathrm{H}_{2} \mathrm{O}}+\mathrm{C}_{\mathrm{Na}}\right) \times 100\right]$ was markedly impaired in the patient, $32 \%$ versus $80 \% \pm 9.2 \%$ in the control subjects. The natriuretic effect of chlorothiazide was normal in the patient, which suggests that the reabsorptive capacity of the thiazide-sensitive segment of the distal nephron is preserved. The evidence presented suggests that the defective reabsorption of sodium in the patient is due to an impaired sodium transport in the ascending limb of Henle's loop. The present study raises the possibility that a similar tubular defect may be responsible for the impaired renal handling of sodium that is often observed in patients with Bartter's syndrome.
\end{abstract}

\section{Speculation}

Impaired transport of sodium localized in the distal nephron, that results in failure of the kidney to conserve salt adequately, is probably the primary disorder in some patients with Bartter's syndrome.

\section{Introduction}

Bartter et al. in 1962 [1] described a disorder characterized by hyperplasia of the juxtaglomerular apparatus, normotensive hyperaldosteronism, absence of edema, and hypokalemic alkalosis. Other features of this syndrome include increased activity of the renin-angiotensin system and growth retardation. Most of the reported patients with Bartter's syndrome had a renal tubular defect in sodium reabsorption $[6,10,21]$.
Bartter et al. [1] postulated that the primary defect in this condition was an unresponsiveness of the vascular bed to angiotensin. However, recent reports have suggested that in some of the patients a defective renal sodium conservation may be the basic abnormality $[6,10]$. The resultant chronic volume depletion activates the renin-angiotensin-aldosterone system effecting excessive urinary excretion of potassium and hypokalemic alkalosis. 
The present report describes a child with the clinical and metabolic features characteristic of Bartter's syndrome, in whom urinary salt wasting was present. Studies were designed to delineate the specific tubular defect in sodium reabsorption. Our findings suggest that salt wastage in this patient is due to a defective transport mechanism at the ascending limb of Henle's loop.

\section{Case Report}

$Z Y$, a 5-year-old male, was admitted to our department with failure to thrive, muscle weakness, polyuria, and polydipsia. Physical examination revealed a small, thin child. His height was $79 \mathrm{~cm}$, weight $7.6 \mathrm{~kg}$, and blood pressure $90 / 50 \mathrm{~mm} \mathrm{Hg}$. All major muscle groups showed weakness and poor tone.

The hematocrit was $41 \%$; the leukocyte count was

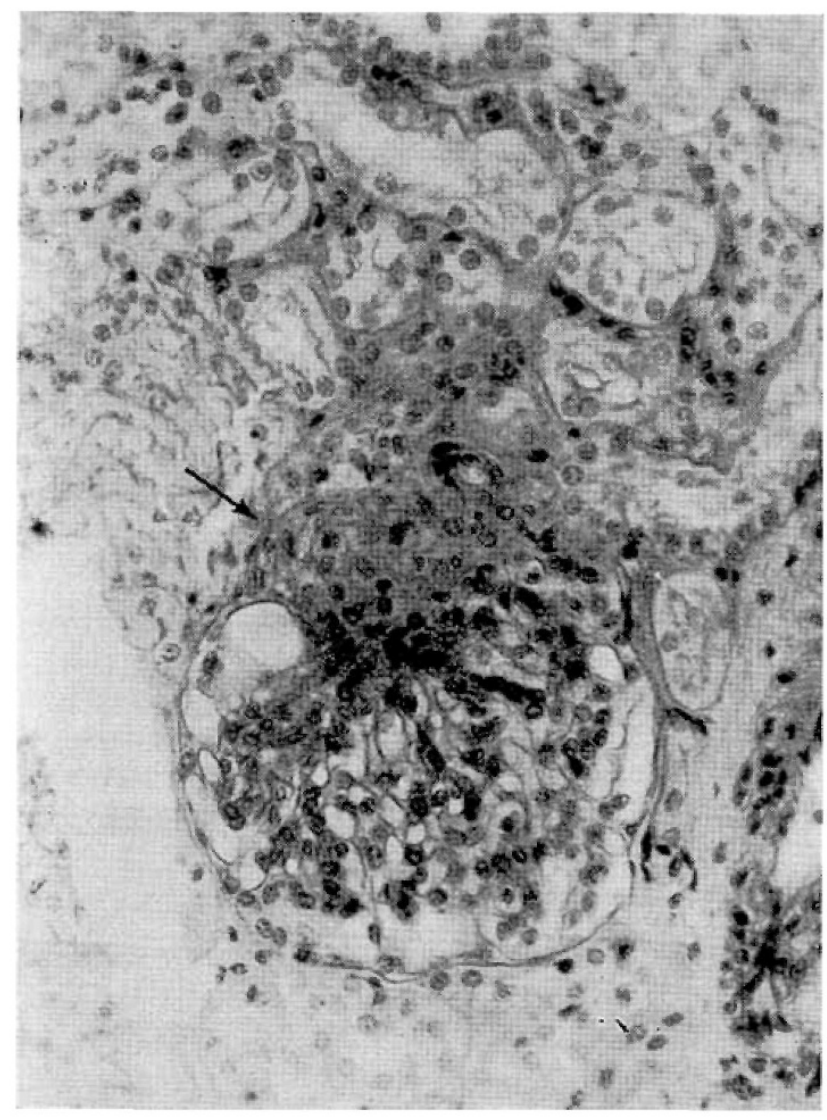

Fig. 1. Glomerulus from needle biopsy, showing hypertrophy of juxtaglomerular apparatus, with hyperplasia and cytoplasmic enlargement of juxtaglomerular apparatus cells. Tubular epithelium shows cytoplasmic pallor suggestive of osmotic nephrosis. Glomerular loops show mild epithelial and mesangial proliferation, but no membrane thickening $(\mathrm{H}-\mathrm{E}) . \times 400$.
$9,000 / \mathrm{mm}^{3}$ with normal differential. Urinalysis and urine culture were negative. Serum sodium was 120 $\mathrm{mEq} /$ liter, potassium $2.0 \mathrm{mEq} /$ liter, chloride $70 \mathrm{mEq} /$ liter, carbon dioxide $32 \mathrm{mEq} /$ liter, calcium $9.8 \mathrm{mg} / 100$ $\mathrm{ml}$, and phosphorus $4.2 \mathrm{mg} / 100 \mathrm{ml}$. Fasting blood sugar was $90 \mathrm{mg} / 100 \mathrm{ml}$ and blood urea nitrogen 6.0 $\mathrm{mg} / 100 \mathrm{ml}$. The $24-\mathrm{hr}$ endogenous creatinine clearance was $80 \mathrm{ml} / \mathrm{min} / 1.73 \mathrm{~m}^{2}$. Urinary $\mathrm{pH}$ was 7.0 and dropped to 5.2 when metabolic acidosis was induced by $\mathrm{NH}_{4} \mathrm{Cl}$ loading. After deprivation of fluids for 10 $\mathrm{hr}$ and the intramuscular injection of $2.5 \mathrm{U}$ pitressin tannate, urinary osmolality was $298 \mathrm{mOsm}$. The $24-\mathrm{hr}$ excretion of potassium in urine was $116 \mathrm{mEq} /$ liter at a time when the serum potassium was $2.4 \mathrm{mEq}$ /liter.

Results of radiographic examination of the chest, skull, and gastrointestinal tract were normal. Intravenous pyelography revealed bilateral mild ureteral dilatation and an enlarged bladder. There was no residual urine in the bladder after voiding.

Renal tissue, obtained by kidney biopsy, was fixed in formalin and stained with hematoxylin and eosin. The glomeruli showed striking hyperplasia of the juxtaglomerular apparatus. The juxtaglomerular cells were pale and had a finely granular cytoplasm (Figs. 1 and 2). Renal functional studies concerning tubular handling of sodium were performed after adequate correction of the salt and volume depletion. Plasma renin concentration could not be determined, as the child was lost to followup.

\section{Methods}

\section{Hypotonic Saline Diuresis}

Studies were performed on the patient and eight healthy control subjects (five young adults and three children aged 11,12, and 15 years). On the morning of the study, each subject received an oral water load of $20 \mathrm{ml} / \mathrm{kg}$ body weight over a 40 -min period. This was followed by the intravenous administration of $0.45 \%$ saline, initially at a rate of $5 \mathrm{ml} / \mathrm{min}$ and subsequently adjusted to exceed urinary flow by $5 \mathrm{ml} / \mathrm{min}$. Hypotonic saline administration was continued until the total dose of $2,000 \mathrm{ml} / 1.73 \mathrm{~m}^{2}$ body surface was infused. Subjects were recumbent during the study but were allowed to stand for voiding. Specimens of urine were obtained by spontaneous voiding at 20 -min intervals. At the midpoint of each urine collection period, samples of venous blood were obtained without stasis from an indwelling needle. After an appropriate priming dose, sustained infusion of inulin in normal saline was adminstered at a rate of $1.0 \mathrm{ml} / \mathrm{min}$ by a constant in- 
fusion pump. The GFR was measured by inulin clearance and corrected to $1.73 \mathrm{~m}^{2}$ body surface.

Solute clearance $\left(\mathrm{C}_{\mathrm{osm}}\right)$, free water clearance $\left(\mathrm{C}_{\mathrm{H}_{2} \mathrm{O}}\right)$, and sodium clearance $\left(\mathrm{C}_{\mathrm{Na}}\right)$ were determined by the following calculations

$$
\mathrm{C}_{\mathrm{osm}}=\frac{\mathrm{U}_{\mathrm{osm}} \mathrm{V}}{\mathrm{P}_{\mathrm{osm}}}, \mathrm{C}_{\mathrm{H}_{2} \mathrm{O}}=\mathrm{V}-\mathrm{C}_{\mathrm{osm}} \text {, and } \mathrm{C}_{\mathrm{Na}}=\frac{\mathrm{U}_{\mathrm{Na}} \mathrm{V}}{\mathrm{P}_{\mathrm{Na}}}
$$

where $\mathrm{V}=$ volume of urine, $\mathrm{U}_{\mathrm{osm}}=$ osmolality of urine, $\mathrm{P}_{\mathrm{osm}}=$ osmolality of plasma, $\mathrm{U}_{\mathrm{Na}}=$ concentration of sodium in urine, and $\mathrm{P}_{\mathrm{Na}}=$ concentration of sodium in plasma. An approximate estimation of the fractional sodium delivery to the distal nephron was obtained from $\left(\mathrm{C}_{\mathrm{H}_{2} \mathrm{O}}+\mathrm{C}_{\mathrm{Na}}\right) / 100 \mathrm{ml} \mathrm{GFR}[18,19]$ and the percentage of distal tubular sodium reabsorption was calculated from $[19,12]$

$$
\frac{\mathrm{C}_{\mathrm{H}_{2} \mathrm{O}}}{\left(\mathrm{C}_{\mathrm{H}_{2} \mathrm{O}}+\mathrm{C}_{\mathrm{Na}}\right)} \times 100
$$

Inulin was analyzed by the method of Smith [17]. Concentrations of sodium and potassium in urine and plasma were determined by standard flame photometry. Osmolality of urine and plasma was measured on a Fiske osmometer.

\section{Sodium Excretion after Chlorothiazide Administration}

The natriuresis affected by chlorothiazide administration was used as an estimate of the rate of sodium reabsorption at the cortical portion of Henle's loop. The study was done according to the protocol described by Earley and Martino [8]. The patient received an oral water load $(20 \mathrm{ml} / \mathrm{kg})$ followed by intravenous infusion of $5 \%$ dextrose (aqueous solution). After urinary flow had stabilized, urine was collected at 10 -min intervals for $30 \mathrm{~min}$. Then $145 \mathrm{mg}$ chlorothiazide $\left(500 \mathrm{mg} / 1.73 \mathrm{~m}^{2}\right.$ body surface) was administered intravenously, followed by constant infusion at a rate of $1.5 \mathrm{mg} / \mathrm{min}$. Urinary losses were replaced by $0.9 \%$ saline containing $15 \mathrm{mEq} \mathrm{KCl} /$ liter. Two more urinary collections at 10 -min intervals were obtained. The GFR was measured by inulin clearance. Venous blood samples were obtained at the midpoint of each urine collection period. Samples of plasma and urine were examined for sodium, potassium, and inulin.

\section{Vasopressor Response to Infusion of Angiotensin II}

After an overnight fast, angiotensin II was infused intravenously at increasing rates $(0.05-0.16 \mu \mathrm{g} / \mathrm{kg} / \mathrm{min})$ into the patient. Blood pressure was recorded every minute during the infusion with the subject recumbent.

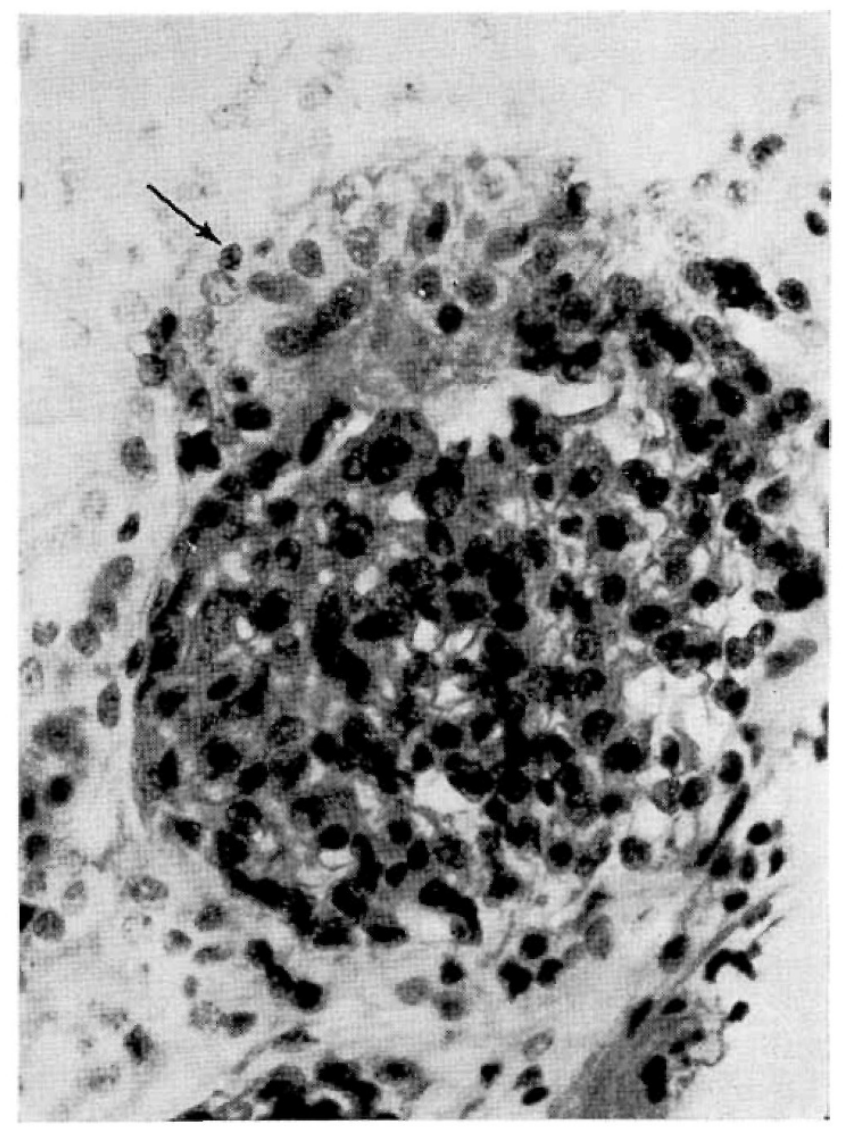

Fig. 2. Glomerulus showing juxtaglomerular apparatus composed of enlarged cells with pale, finely granular cytoplasm (H-E). $\times 550$.

\section{Results}

\section{Renal Function during Hypotonic Saline Diuresis}

Data obtained for the patient and for the control subjects during hypotonic saline diuresis are outlined in Table I and Figure 3. The figures represent data at the period of maximal free water clearance.

The mean value for GFR in the patient $(128 \mathrm{ml} /$ $\left.\min / 1.73 \mathrm{~m}^{2}\right)$ is similar to the value in the controls $\left(129 \pm 30.1 \mathrm{ml} / \mathrm{min} / 1.73 \mathrm{~m}^{2}\right)$. Fractional free water clearance of the patient was less than half that observed in control subjects $(4.2$ versus $9.0 \pm 3.1 \mathrm{ml} / \mathrm{min} / 100 \mathrm{ml}$ GFR). Urine osmolality was 204 and $103 \pm 20 \mathrm{mOsm}$ in patient and control subjects, respectively. Fractional sodium clearance in the patient was $9.1 \mathrm{ml} / \mathrm{min} / 100$ $\mathrm{ml} \mathrm{GFR} \mathrm{versus} \mathrm{a} \mathrm{value} \mathrm{of} 2.1 \pm 0.9$ in the control subjects.

Fractional distal tubule sodium load, in $\mathrm{ml} / \mathrm{min} / 100$ $\mathrm{ml}$ GFR, as evaluated by $\left(\mathrm{C}_{\mathrm{H}_{2} \mathrm{O}}+\mathrm{C}_{\mathrm{Na}}\right) / 100 \mathrm{ml}$ GFR was 13.3 in the patient and $11.00 \pm 3.5$ in the control subjects. Fractional urinary flow values of 16.9 and 
Table I. Data from period of maximal free water clearance during hypotonic saline diuresis ${ }^{1}$

\begin{tabular}{|c|c|c|c|c|c|c|c|c|c|c|c|c|}
\hline & $\begin{array}{c}\mathrm{V}, \mathrm{ml} / \mathrm{min} / \\
100 \mathrm{GFR}\end{array}$ & $\underset{\mathrm{m}^{2}}{\mathrm{C}_{\mathrm{Tn}}, \mathrm{ml} / \mathrm{m} / \mathrm{I}}$ & $\underset{\underset{\mathrm{H}_{2} \mathrm{O}}{\mathrm{U}_{\mathrm{osm}}}}{\mathrm{mOsm} / \mathrm{kg}}$ & $\begin{array}{c}\text { Cosm, } \\
\mathrm{ml} / \mathrm{min} / \\
100 \mathrm{ml} \\
\text { GFR }\end{array}$ & $\begin{array}{c}\mathrm{C}_{\mathrm{H}_{2} \mathrm{O}}, \mathrm{ml} / \\
\min / 100 \\
\mathrm{ml} \mathrm{GFR}\end{array}$ & $\begin{array}{c}\mathrm{UNa}_{\mathrm{Na}} \\
\mu \mathrm{Eq} / \mathrm{min} / \\
100 \mathrm{ml} \\
\mathrm{GFR}\end{array}$ & $\begin{array}{c}\mathrm{C}_{\mathrm{Na}}, \mathrm{ml} / \\
\mathrm{min} / 100 \\
\mathrm{ml} \mathrm{GFR}\end{array}$ & $\begin{array}{c}\mathrm{C}_{\mathrm{H}_{2} \mathrm{O}}+ \\
\mathrm{C}_{\mathrm{Na}} \mathrm{mi} / \mathrm{ml} \\
\mathrm{min} / 100 \\
\mathrm{ml} \text { GFR }\end{array}$ & $\begin{array}{l}\mathrm{C}_{\mathrm{H}_{2} \mathrm{O}} / \\
\mathrm{C}_{\mathrm{H}_{2} \mathrm{O}}+ \\
\mathrm{C}_{2} \mathrm{X} \\
100, \%\end{array}$ & $\begin{array}{c}\mathrm{UKV} \\
\mu \mathrm{Eq} / \mathrm{min} / \\
100 \mathrm{ml} \\
\mathrm{GFR}\end{array}$ & $\begin{array}{c}\mathrm{P}_{\mathrm{Na}}, \\
\mathrm{mEq} / \text { liter }\end{array}$ & $\begin{array}{c}\mathrm{PK}, \\
\mathrm{mEq} / \mathrm{liter}\end{array}$ \\
\hline Patient & 16.9 & 128 & 204 & 12.7 & 4.2 & 1132 & 9.1 & 13.1 & 32 & 256 & 125 & 3.2 \\
\hline Control subjects ${ }^{2}$ & 13.7 & 129 & 103 & 4.5 & 9.0 & 282 & 2.1 & 11.1 & 80 & 78.2 & $2 \quad 136$ & 3.5 \\
\hline & \pm 3.9 & \pm 30 & \pm 3.1 & \pm 1.1 & \pm 3.1 & \pm 118 & \pm 0.9 & \pm 3.5 & \pm 9.2 & \pm 32 & \pm 3.6 & \pm 0.2 \\
\hline
\end{tabular}

$1 \mathrm{~V}$ : Urine volume; GFR: glomerulas filtration rate; $\mathrm{C}_{\mathrm{In}_{n}}$ : inulin clearance; $\mathrm{U}_{\text {osm }}$ : urinary osmolality; $\mathrm{C}_{\mathrm{osm}}$ : osmotic clearance; $\mathrm{C}_{\mathrm{H}_{2} \mathrm{O}}$ : free water clearance; $\mathrm{U}_{\mathrm{Na}} \mathrm{V}$ : rate of sodium excretion; $\mathrm{C}_{\mathrm{Na}}$ : sodium clearance; $\mathrm{C}_{\mathrm{H}_{2} \mathrm{O}}+\mathrm{C}_{\mathrm{Na}}$ : distal load of sodium : $\mathrm{C}_{\mathrm{H}_{2} \mathrm{O}} / \mathrm{C}_{\mathrm{H}_{2} \mathrm{O}}$ $+\mathrm{C}_{\mathrm{Na}} \times 100$ : percentage of sodium reabsorption in distal tubule; $\mathrm{U}_{\mathrm{KV}}$ : rate of potassium excretion; $\mathrm{P}_{\mathrm{Na}}$ : serum sodium concentration; $P_{K}$ : serum potassium concentration.

${ }^{2}$ Values are the means \pm SD in eight healthy control subjects.
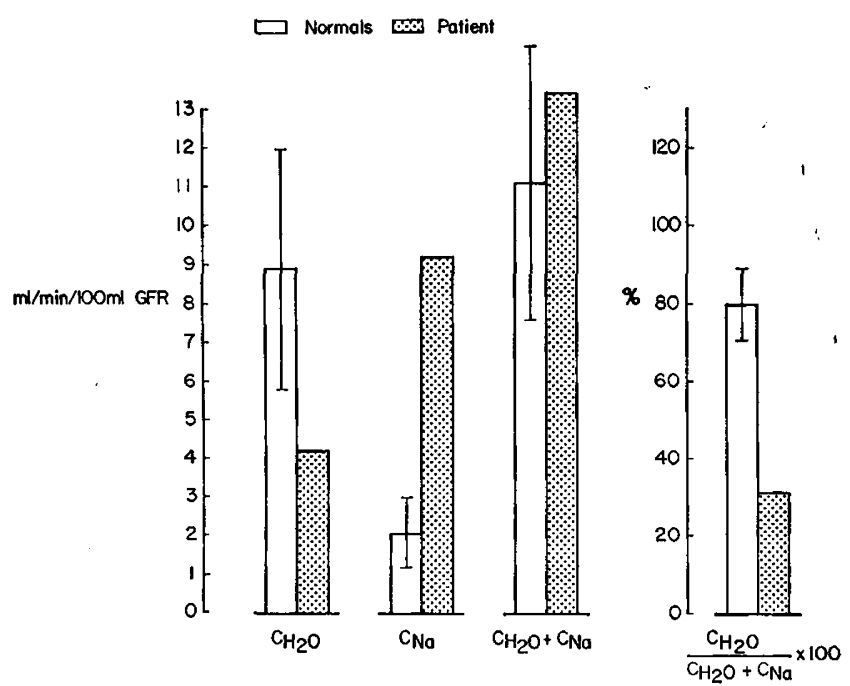

Fig. 3. Free water clearance, sodium clearance, distal sodium load, and distal sodium reabsorption during peak free water clearance. Open bars: Control subjects. Dotted bars: The patient. GFR: Glomerular filtration rate.

$13.7 \pm 3.9 \mathrm{ml} / 100 \mathrm{ml}$ GFR in the patient and controls subjects, respectively, suggested that the proximal tubular reabsorption of sodium was not significantly impaired.

Sodium transport at the diluting segment $\left[\left(\mathrm{C}_{\mathrm{H}_{2} \mathrm{O}} /\right.\right.$ $\left.\left.\mathrm{C}_{\mathrm{H}_{2} \mathrm{O}}+\mathrm{C}_{\mathrm{Na}}\right) \times 100\right]$ was markedly depressed in the patient (32\%) as compared with the value in the controls $(80 \% \pm 9.2 \%)$.

The relation of $\mathrm{C}_{\mathrm{E}_{2} \mathrm{O}}$ and $\left(\mathrm{C}_{\mathrm{H}_{2} \mathrm{O}}+\mathrm{C}_{\mathrm{Na}}\right)$ in the patient and in the control group (Fig. 4) indicates that in the patient sodium transport was impaired, not only at peak water diuresis, but also at all rates of distal tubular sodium delivery examined in this study.

\section{Natriuretic Effect of Chlorothiazide}

Excretion of sodium in urine, in $\mu \mathrm{Eq} / \mathrm{min} / 100 \mathrm{ml}$ GFR, increased in the patient from a control value of
945 to 2,229. Earley and Martino [8] detected that in normal healthy subjects the increment in excretion of sodium in urine after chlorothiazide treatment was 690 $\pm 249 \mu \mathrm{Eq} / \mathrm{min}$ (mean GFR $99 \mathrm{ml} / \mathrm{min}$ ) during normal sodium intake. Moreover, these authors demonstrated that when sodium delivery to the distal tubule is increased, as after salt loading, normal subjects have a more pronounced natriuresis after chlorothiazide $(1,549$ $\pm 607 \mu \mathrm{Eq} / \mathrm{min}$, mean GFR $137 \mathrm{ml} / \mathrm{min}$ ).

\section{Responsiveness of Blood Pressure to Angiotensin}

Insensitivity to angiotensin was marked in the patient as demonstrated by lack of vasopressor response during the study. Normal adults show marked increases in blood pressure when rates of infusion of angiotensin are less than $0.1 \mu \mathrm{g} / \mathrm{kg} / \mathrm{min}$ [13].

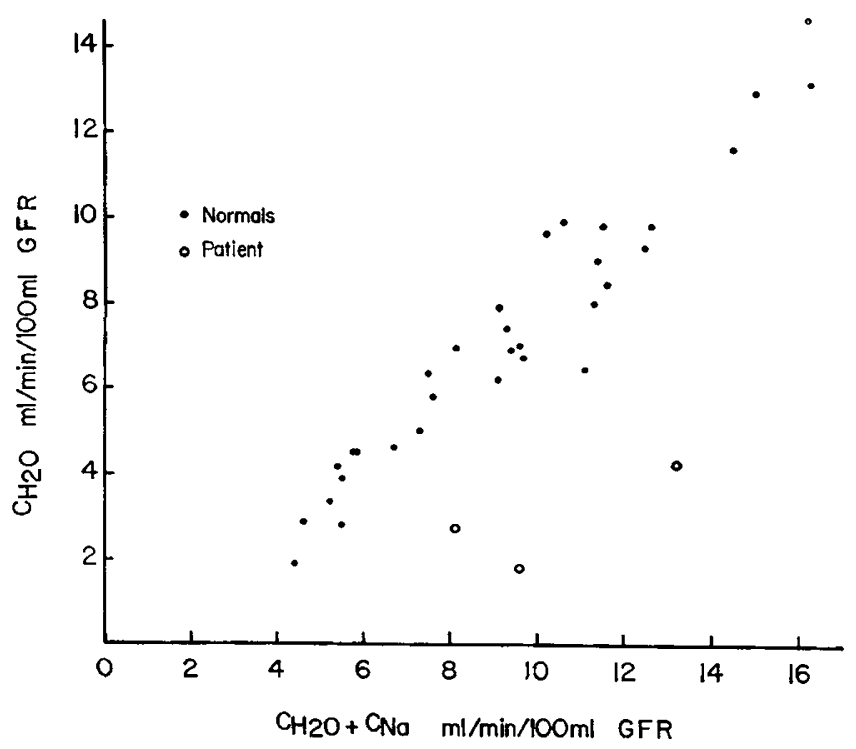

Fig. 4. Relation between fractional free water clearance and fractional distal sodium delivery during hypotonic saline diuresis. -: Normal control subjects. O: Our patient. GFR: Glomerular filtration rate. 


\section{Discussion}

The primary defect in Bartter's syndrome is unknown. Bartter et al. [1] suggested that the primary abnormality was an impaired vascular responsiveness to angiotensin leading to overproduction of renin and hyperaldosteronism. In several reports [6, 10], however, defective renal conservation of sodium was described. The authors suggested that renal salt wasting resulted in chronic depletion of the extracellular fluid which led to hypertrophy of the juxtaglomerular cells, hyperreninemia, and increased aldosterone production. The demonstration that a fall in the plasma renin level follows the expansion of plasma volume in some patients with Bartter's syndrome $[2,10,21]$ further suggests that the hypersecretion of renin in these cases is compensatory to hypovolemia.

The nature of the sodium reabsorptive defect in Bartter's syndrome and its localization in the nephron have not been established. Therefore, we studied the site of the renal tubular defect in a patient with Bartter's syndrome by utilizing both clearance and diuretic blockade methodologies.

During hypotonic saline loading, expansion of extracellular fluid resulted in a progressive inhibition of sodium reabsorption at the proximal tubule, thereby increasing delivery of filtrate to the distal nephron $[7,9,14]$. At peak free water diuresis, when antidiuretic hormone activity is minimal or absent, $\left(\mathrm{C}_{\mathrm{H}_{2} \mathrm{O}}+\mathrm{C}_{\mathrm{Na}}\right)$ $[18,19]$ provides an indirect index of distal sodium supply and the urinary flow represents the volume of filtrate reaching the ascending limb [16].

The present results demonstrate that the fraction of the glomerular filtrate that escaped proximal tubule reabsorption (volume/100 $\mathrm{ml} \mathrm{GFR)} \mathrm{and} \mathrm{rate} \mathrm{of} \mathrm{de-}$ livery of sodium to the distal nephron $\left(\mathrm{C}_{\mathrm{H}_{2} \mathrm{O}}+\mathrm{C}_{\mathrm{Na}} /\right.$ $100 \mathrm{ml} \mathrm{GFR}$ ) were within normal range in our patient. Consistent with these findings are the observations of White [21], which suggest normal handling of sodium by the proximal tubule in Bartter's syndrome. However, it is possible that the patient had some degree of extracellular fluid contraction before the saline infusion because of his urinary salt wasting. Under such circumstances, a comparable value for the rate of sodium delivery to the distal nephron in normal subjects and in the patient must be interpreted with caution. If extracellular volume contraction was present in the patient, distal delivery of sodium similar to that observed in normal subjects may indeed suggest that proximal reabsorption of sodium in the patient was impaired.
During hypotonic saline diuresis, free water clearance was low and sodium excretion markedly increased in the patient. It is well established that the rate of solute free water generation depends primarily upon sodium transport without water at the ascending limb of Henle's loop [9, 16]. The functional integrity of this transport mechanism can be detected when high rates of sodium are delivered to the water clearing segment, as occurs during hypotonic saline diuresis. During this procedure, the amount of free water clearance is an estimate of the sodium reabsorptive capacity of the ascending limb of Henle's loop [9, 16]. The present data indicate that free water formation was markedly reduced for any given rate of distal tubule sodium delivery in our patient. Salt wasting, therefore, is mainly a consequence of a defect of sodium transport at the ascending limb of Henle's loop.

The ascending limb of Henle's loop consists of two diluting segments that differ in both their anatomical and functional characteristics, the medullary and the cortical diluting segments [16]. Chlorothiazide has been shown to inhibit selectively sodium reabsorption at the cortical diluting segment [11]. The natriuretic effect of chlorothiazide in our patient was comparable to that seen in healthy subjects in whom the sodium load to the distal tubule was increased [8]. This observation suggests that the reabsorptive capacity of the thiazide-sensitive portion of the distal nephron was not affected in the patient. Our findings may therefore indicate that the defect in sodium reabsorption is probably located primarily in the medullary portion of the ascending limb of Henle's loop.

Defective sodium reabsorption in the ascending limb of Henle's loop impairs the ability of the kidney to develop an adequate medullary hyperosmolarity [20]. This reduces back diffusion of free water at the collecting tubules and thereby accounts for our patient's inability to produce concentrated urine during hydropenia. In addition, the severe hypokalemia may have contributed to the hyposthenuria [15].

Several lines of evidence have shown that the distal tubular potassium secretion rate is enhanced by an increased sodium delivery to the distal tubule [3]. Then, marked kaliuresis in our patient can be explained by the large amount of rejected sodium presented to the distal tubule sodium-potassium exchange site. Hyperaldosteronism may further accentuate this exchange and enhance urinary potassium wastage.

Renal salt losing may also account for the vascular unresponsiveness to angiotensin. Recent studies have shown a relation between the concentration of renin 
in plasma, the state of sodium balance, and the pharmacologic effect of angiotensin [4, 5]. Both increased plasma renin activity and sodium depletion are associated with reduced vasopressor response to angiotensin [4]. Accordingly, the impaired vascular response seen in our patient could have resulted from both negative sodium balance and hyperreninemia (the level of renin in plasma was not measured in our patient but was presumed to be elevated). This concept is reinforced by the observation that normal vasopressor response to angiotensin in patients with Bartter's syndrome was restored after expansion of the vascular volume by albumin or saline infusion $[10,21]$.

Although renal sodium wasting was well documented in some patients with Bartter's syndrome [4, 6], most of the reported cases achieved a normal sodium balance with salt restriction [10,21]. According to Cannon et al. [6], these patients, in whom "obligatory" salt loss was ruled out, may have a milder tubular defect, and an accelerated sodium-potassium exchange at the distal tubule can prevent the urinary salt wasting. As was shown by White [21], however, when the tubular transport system is challenged by a sodium load, the inability of the renal tubule to reabsorb sodium normally becomes apparent in these patients.

On the basis of the present data, we suggest that salt losing in our patient results from an impaired transport of sodium out of the ascending limb of Henle's loop and that a similar mechanism may explain the defective renal sodium handling seen in some patients with Bartter's syndrome.

\section{References and Notes}

1. Bartter, F. C., Pronove, P., Gill, J. R., JR., and MacGardle, R. C.: Hypexplasia of the juxtaglomerular complex with hyperaldosteronism and hypokalemic alkalosis. Amer. J. Med., 33: 811 (1962).

2. Beilin, L. J., Schiffman, N., and Crane, M., ex al.: Hypokalemic alkalosis and hyperplasia of the juxtaglomerular apparatus without hypertension or oedema. Brit. Med. J., 4: 327 (1967).

3. BERLINER, R. W.: Renal mechanism for potassium excretion. Harvey Lect., 55: 141 (1960).

4. Bianchi, G., Brown, T. T., Lever, A. F., Robertson, J. I. S., AND Roth, N.: Changes of plasma renin concentration during pressor infusion of renin in the conscious dog: The influence of dietary sodium intake. Clin. Sci., 34: 303 (1968).

5. Brown, T. T., Davis, D. L., Lever, A. F., Robertson, T. I. S., AND Bianchi, G. ET AL.: Renin and blood pressure. Proceedings of the Third International Congress of Nephrology, Washington (1966).
6. Cannon, P. J., Leeming, J. M., Sommers, S. C., Winters, R. W., AND LARAGH, J. H.: Juxtaglomerular cell hyperplasia and secondary hyperaldosteronism (Bartter's syndrome): A reevaluation of the pathophysiology. Medicine, 47: 107 (1968).

7. Dirks, J. H., Cirskena, W. J., and Berliner, R. W.: The effect of saline infusion on sodium reabsorption by the proximal tubule of the dog. J. Clin. Invest., 44: 1160 (1965).

8. Earley, L. G., and Martino, T. A.: Influence of sodium balance on the ability of diuretics to inhibit tubular reabsorption. A study of factors that influence renal tubular sodium reabsorption in man. Circulation, 42: 323 (1970).

9. Eknoyan, G., Sukx, W. N., Rector, F. C., JR., And Seldin, D. W.: Functional characteristics of the diluting segment of the dog nephron and the effect of extracellular volume expansion on its reabsorptive capacity. J. Clin. Invest., 1178 (1967).

10. Goodman, A. D., Vagnucci, A. D., Vagnucci, A. H., And Hartroft, P. M.: Pathogenesis of Bartter's syndrome. New Engl. J. Med., 281: 1436 (1969).

11. Heinemann, H. O., Demartini, F. E., and Laragh, T. H.: The effect of chlorothiazide on renal excretion of electrolyte and free water. Amer. J. Med., 26: 853 (1959).

12. Kaloyanides, G. J., Cacciagvida, N. C. P., and Porush, J. G.: Increased sodium reabsorption in the proximal and distal tubule of caval dogs. J. Clin. Invest., 48: 1543 (1969).

13. Kaplan, N. M., and Silah, J. G.: The effect of angiotensin II on the blood pressure in humans with hypertensive disease. J. Clin. Invest., 43: 659 (1964).

14. Levinskx, N. G. and Lalone, C. R.: The mechanism of sodium diuresis after saline infusion in the dog. J. Clin. Invest., 42: 1261 (1963).

15. Relman, A. S., and Schwartz, W. B.: In: Renal disease. D. A. K. Black: The Kidney and Potassium Metabolism. (Davis, Philadelphia, 1963).

16. Seldin, D. W., Eknoyan, G., Suki, W. N., And Recror, F. C., JR.: Localization of diuretic action from the pattern of water and electrolyte excretion. Ann. N. Y. Acad. Sci., 139: 328 (1966).

17. Smith, H. W.: Principles of Renal Physiology, p. 208. (Oxford University Press, New York, 1956).

18. Stein, R. M., Abramson, R. G., Bercovitch, D. D., AND LEVITT, M. F.: Effect of unilateral renal arterial constriction on tubular reabsorption of sodium and water during an osmotic diuresis. J. Clin. Invest., 44: 1720 (1965).

19. Stein, R. M., Abramson, R. G., Kahn, T., and Levitx, M. F.: Effect of hypotonic saline loading in hydrated dog: evidence for a saline-induced limit on distal tubular sodium transport. J. Clin. Invest., 46: 1205 (1967).

20. Suki, W. N., Eknoyan, G., Rector, F. G., JR., and Seldin, D. W.: The renal diluting and concentrating mechanism in hypercalcemia. Nephron, 6: 50 (1969).

21. Whrte, M. G.: Bartter's syndrome. Arch. Int. Med., 129: 41 (1972).

22. We are indebted to Richard M. Fine, M.D., and Shaul G. Massry, M.D., for their help and advice, and to Mrs. Catherine Hoyt for her secretarial assistance.

23. Requests for reprints should be addressed to: Cidio Charmovrtz, M.D., Cedars-Sinai Medical Center, 8720 Beverly Boulevard, Los Angeles, Calif. 90048 (USA).

24. Accepted for publication October 30, 1972. 